\title{
The effect of decrease in body temperature with Nembutal on meiosis and ovulation after induction by gonadotrophin- releasing hormone and luteinizing hormone in adult rats
}

\author{
J. A. M. Mattheij, J. J. M. Swarts, K. H. van het Hof, J. Verburg and \\ J. Visser
}

Department of Human and Animal Physiology, Agricultural University, Wageningen, The Netherlands

\begin{abstract}
Summary. Sodium pentobarbital (Nembutal) is often used to block the pro-oestrous luteinizing hormone ( $\mathrm{LH})$ surge in rats. Nembutal is also known to lower body temperature. This study was designed to investigate whether Nembutal affected the time course of meiosis and timing of ovulation induced by exogenous hormones, and whether the possible effects of Nembutal on these processes were related to temperature. Gonadotrophin-releasing hormone (GnRH), the GnRH-analogue Ovalyse, or rat luteinizing hormone $(\mathrm{LH})$ were administered to trigger resumption of meiosis and ovulation; Nembutal ( $35 \mathrm{mg} \mathrm{kg}^{-1}$ body weight) or saline was given 10 or $60 \mathrm{~min}$ later. Plasma profiles of LH were measured and Graafian follicles were studied histologically for meiotic progress and ovulation. Nembutal suppressed the spontaneous surge of LH at pro-oestrus and caused a long-lasting decrease in body temperature. If $1000 \mathrm{ng}$ GnRH was given $2 \mathrm{~h}$ before the pro-oestrous LH surge, most of the oocytes had extruded a polar body $10 \mathrm{~h}$ later and most follicles had ovulated $14 \mathrm{~h}$ later. Nembutal given I $\mathrm{h}$ after $\mathrm{GnRH}$ delayed extrusion of the polar body and ovulation by about $2 \mathrm{~h}$. Nembutal caused a similar delay in ovulation when it was administered after $100 \mathrm{ng}$ of Ovalyse, and it also delayed meiosis when given after $1000 \mathrm{ng}$ of $\mathrm{LH}$. This effect of Nembutal was prevented if body temperature was maintained at $37^{\circ} \mathrm{C}$. The delaying effect of Nembutal on meiosis and ovulation induced by exogenous GnRH or LH is related to a long-lasting decrease in body temperature.
\end{abstract}

Ke f'iords: Nembutal; temperature; meiosis; ovulation; rat

\section{Introduction}

Resumption of meiosis and ovulation is triggered by a surge of luteinizing hormone (LH) on the day of pro-oestrus in mammals. The LH surge has a diurnal rhythm (Everett \& Sawyer, 1950) and begins about $2 \mathrm{~h}$ after the middle of the light period in rats (Everett et al., 1949). Ovulation occurs about $14 \mathrm{~h}$ after the onset of the spontaneous LH surge (Sridaran et al., 1979). Sodium pentobarbital (Nembutal) administered before the presumed surge of LH on pro-oestrus suppresses this LH secretion (Everett \& Sawyer, 1950; Daane \& Parlow, 1971) and postpones ovulation by 1 day (Everett \& Sawyer, 1950; van der Schoot, 1980). Nembutal-treated pro-oestrous rats may therefore be used as a model to study the temporal aspects of meiosis, ovulation and luteinization. However, the dose of Nembutal used to block spontaneous ovulation causes a considerable and long-lasting reduction of body temperature (Janocko \& Mycek, 1986). It is possible that decreased body temperature retards various biochemical processes; thus meiotic progress and ovulation induced by exogenous gonadotrophins may be retarded in rats anaesthetized with Nembutal. This study investigated how far Nembutal interferes with progression of meiosis and ovulation induced by 
exogenous $\mathrm{LH}$ or gonadotrophin-releasing hormone $(\mathrm{GnRH})$. We also examined whether temporal aspects of meiosis and ovulation in rats anaesthetized with Nembutal remained normal when a decrease in body temperature of the rats was prevented.

\section{Materials and Methods}

\section{Animals and treatments}

The trials used virgin female $F_{1}$ hybrid rats of two Wistar substrains ( $\mathrm{U}$-inbred males and $\mathrm{R}$-inbred females), aged 3-5 months and weighing $220-240 \mathrm{~g}$. Rats were housed individually under controlled conditions of temperature

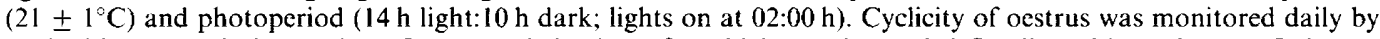
vaginal lavage and observation of oestrous behaviour, for which a male was briefly allowed in each cage. Only rats with three consecutive 5 day cycles were used. The rats that were used for blood sampling were supplied with a permanent indwelling cannula of the jugular vein (Mattheij \& van Pijkeren, 1977). Cyclicity of oestrus was monitored in these rats from the day after implantation of the cannula.

Body temperature was measured in pro-oestrous rats by a deep rectal thermometer, using a Keith Ley electrode type $A$ thermometer. The thermometer was pushed gently into the rectum to a depth of $4 \mathrm{~cm}$ and kept in place for $1 \mathrm{~min}$ for each measurement. Because the rats were used to daily handling, the method was also used with conscious rats. Temperature was measured in nine untreated rats at intervals of one hour between 09:00 and 17:00 h, and in nine Nembutal-treated rats at intervals of $15 \mathrm{~min}$. The ambient temperature at which a decrease in body temperature could be prevented was assessed by injecting groups of six rats with Nembutal and subsequently placing them in a climatic chamber at $31,32,33$ or $34 \cdot 5^{\circ} \mathrm{C}$, respectively; body temperature was measured before and at intervals of $2 \mathrm{~h}$ for $8 \mathrm{~h}$ afterwards. The climatic chamber was equipped for biochemical work; temperature fluctuations around a set temperature were less than $0.5^{\circ} \mathrm{C}$.

\section{Materials}

GnRH was purchased from Calbiochem (LHRF, Lot 286031). Ovalyse (des- ${ }^{10} \mathrm{GnRH}$-ethylamide) was a gift from Upjohn, Ede, The Netherlands. The LH used was rat LH obtained from the NIDDK (r-LH-16; AFP-6833C) (Bethesda, MD). The hormones were dissolved in saline containing $1 \%$ bovine serum albumin (Sigma RIA-grade). Hormone injections were given intravenously (i.v.). Nembutal (sodium pentobarbital) was obtained from Sanofi, Maassluis, The Netherlands. In all experiments, Nembutal was given intraperitoneally (i.p.) at a dose of $35 \mathrm{mg} \mathrm{kg}^{-1}$ body weight, in a volume of $0 \cdot 12-0 \cdot 14 \mathrm{ml}$. Controls received a similar amount of saline i.p.

\section{Radioimmunoassay}

Blood samples, $0.25 \mathrm{ml}$, were collected in heparinized tubes on ice. After centrifugation plasma samples of $0.1 \mathrm{ml}$ were diluted with 2 volumes of phosphate-saline buffer $\left(\mathrm{pH} \mathrm{7.5)}\right.$ and stored at $-25^{\circ} \mathrm{C}$. LH was measured by radioimmunoassay (RIA), using materials provided by NIDDK. $\mathrm{r}-\mathrm{LH}-16$ was labelled with ${ }^{125} \mathrm{I}$; anti-rLH-S10 was used as first antibody; rLH RP2 was used as LH standard. The second antibody was donkey-anti-rabbit (Sac-cel, Wellcome Reagents, Beckenham, England). The variation within and between assays in relative standard deviation were $7.4 \%$ and $10.9 \%$, respectively. The detection level of the assay was $0.1 \mathrm{ng}$ per tube at $90 \% \mathrm{~B}: \mathrm{B}_{0}$ level.

\section{Histology}

Ovaries were fixed in Bouin's solution and embedded in paraffin wax. Serial sections $(10 \mu \mathrm{m})$ were stained with Harris' haematoxylin (Gurr, GB) and eosin, and mounted in DePeX (Gurr, GB). In both ovaries of each rat, healthy follicles exceeding $600 \mu \mathrm{m}$ and number of ruptured follicles were counted. Ruptured follicles could easily be distinguished from corpora lutea, because the former were compact structures containing numerous small dark-staining nuclei. Large follicles with signs of atresia were excluded. For assessment of meiotic progress, metaphase I, anaphase and telophase were considered together as 'MAT' stage. Because the first polar body disappears rapidly (Tsafriri \& Kraicer, 1972), we could divide metaphase-II oocytes into two categories: metaphase II with visible polar body, i.e. within $2 \mathrm{~h}$ of reaching telophase; and metaphase II without polar body, i.e. more than $2 \mathrm{~h}$ after extrusion.

\section{Experiments}

In Expt 1, the timing and magnitude of the pro-oestrous surge of LH were measured at intervals of one hour between 10:00 and 16:00 h $(n=9)$; the suppressive effect of Nembutal on this surge was verified $(n=9)$. In Expts 
Table 1. Procedure for expts $2-4$

\begin{tabular}{|c|c|c|c|c|c|c|}
\hline & $\begin{array}{l}\text { Time of } \\
\text { hormone } \\
\text { injection }\end{array}$ & $\begin{array}{l}\text { S (saline) or } \\
\text { N (Nembutal) }\end{array}$ & $n$ & $\begin{array}{l}\text { Temp. } \\
\left({ }^{\circ} \mathrm{C}\right)\end{array}$ & $\begin{array}{l}\text { Blood samples } \\
\text { from }\end{array}$ & $\begin{array}{l}\text { Histology, } \\
\text { interval after } \\
\text { hormone (h) }\end{array}$ \\
\hline \multirow{4}{*}{$\begin{array}{l}\text { Experiment } 2 \\
(1000 \text { ng GnRH) }\end{array}$} & \multirow[t]{4}{*}{ 10:00 h Pro. } & $\mathrm{S}$ & 7 & 21 & $10: 00-16: 00 \mathrm{~h}$ & - \\
\hline & & $\mathrm{S}$ & 15 & 21 & - & $10,12,14$ \\
\hline & & $\mathrm{N}$ & 7 & 21 & $10: 00-16: 00 \mathrm{~h}$ & - \\
\hline & & $\mathrm{N}$ & 17 & 21 & - & $10,12,14$ \\
\hline Experiment 3 & 16:00 h di-3. & $\mathrm{S}$ & 12 & $2 \mathrm{I}$ & - & $12,14,16$ \\
\hline \multirow[t]{5}{*}{ (100 ng Ovalyse) } & \multirow[t]{5}{*}{ 10:00 h Pro. } & $\mathrm{S}$ & 9 & 21 & $10: 00-14: 00 \mathrm{~h}$ & - \\
\hline & & $\mathrm{S}$ & 12 & 21 & - & $12,14,16$ \\
\hline & & $\mathrm{N}$ & 9 & 21 & $10: 00-[4: 00 \mathrm{~h}$ & - \\
\hline & & $\mathbf{N}$ & 16 & 21 & - & $12,14,16,18$ \\
\hline & & $\mathrm{N}$ & 12 & 33 & - & $12,14,16$ \\
\hline \multirow{3}{*}{$\begin{array}{l}\text { Experiment } 4 \\
(1000 \mathrm{ng} \mathrm{LH})\end{array}$} & \multirow[t]{3}{*}{ 00:00 h Pro. } & $\mathbf{S}$ & 9 & 21 & - & 10 \\
\hline & & $\mathrm{N}$ & 9 & 21 & - & 10 \\
\hline & & $\mathrm{N}$ & 9 & 33 & - & 10 \\
\hline
\end{tabular}

Pro.: pro-oestrus; di-3.: day 3 of dioestrus; Temp.: temperature of rat room; $n$ : number of rats tested; - not performed: GnRH: gonadotrophin-releasing hormone; LH: luteinizing hormone.

24 , we studied the effect of Nembutal on time course of meiosis and on time of ovulation induced by exogenous hormones. The experimental outline of these experiments is summarized (Table 1).

In Expt 2, GnRH, $1000 \mathrm{ng}$, was injected; this dose previously induced normal ovulation in 5-day cyclic rats when given on day 3 of dioestrus (Mattheij et al., 1986). In Expt 3, $100 \mathrm{ng}$ of Ovalyse, a potent LH-releasing GnRH analogue, was injected. In Expt 4, $1000 \mathrm{ng}$ of rat $\mathrm{LH}$ was injected; in a pilot study, $500 \mathrm{ng}$ of $\mathrm{LH}$ triggered meiotic resumption in less than $20 \%$ of the oocytes and $1000 \mathrm{ng}$ induced meiosis in more than $60 \%$ of the oocytes. In Expts 2 and 3. Nembutal was given 60 min after GnRH or Ovalyse, whereas in Expt 4 Nembutal was given 10 min after LH. In Expt 2, blood was taken every 20 min during the first hour and later at intervals of one hour. In Expt 3, blood was taken every half hour. Total reduction of blood volume in any rat was less $20 \%$; we therefore did not return the removed blood cells suspended in saline.

\section{Statistical analysis}

Plasma LH profiles were evaluated by split-plot analysis of variance (Gill \& Hafs, 1971). Two-sample comparisons of paired and independent LH concentrations were made by Student's $t$ test (Snedecor \& Cochran, 1989). This test was also used to evaluate the temperature data. The histological data were analysed, using Mann-Whitney's U test (Snedecor \& Cochran, 1989). Values of $P<0.05$ were considered significant. All data were expressed as means with SEM.

\section{Results}

\section{Effect of Nembutal on body temperature}

After administration of Nembutal, body temperature decreased rapidly, reaching a nadir of $(28.5 \pm 0.5)^{\circ} \mathrm{C}$ between 2 and $3 \mathrm{~h}$ after injection of Nembutal (Fig. 1a). The Nembutal-induced fall of temperature was partly or completely prevented at higher ambient temperatures (Fig. Ib); at a room temperature of $33^{\circ} \mathrm{C}$, the rats maintained normal body temperature. Ambient temperature was therefore kept at $33^{\circ} \mathrm{C}$ to maintain normal body temperature after Nembutal injection in parts of Expts 3 and 4.

\section{Experiment 1}

From 12:00 h onwards, a significant increase in LH concentration was observed $(P<0 \cdot 05)$; Nembutal administered at 10:00 h completely prevented this surge (Fig. 2). 

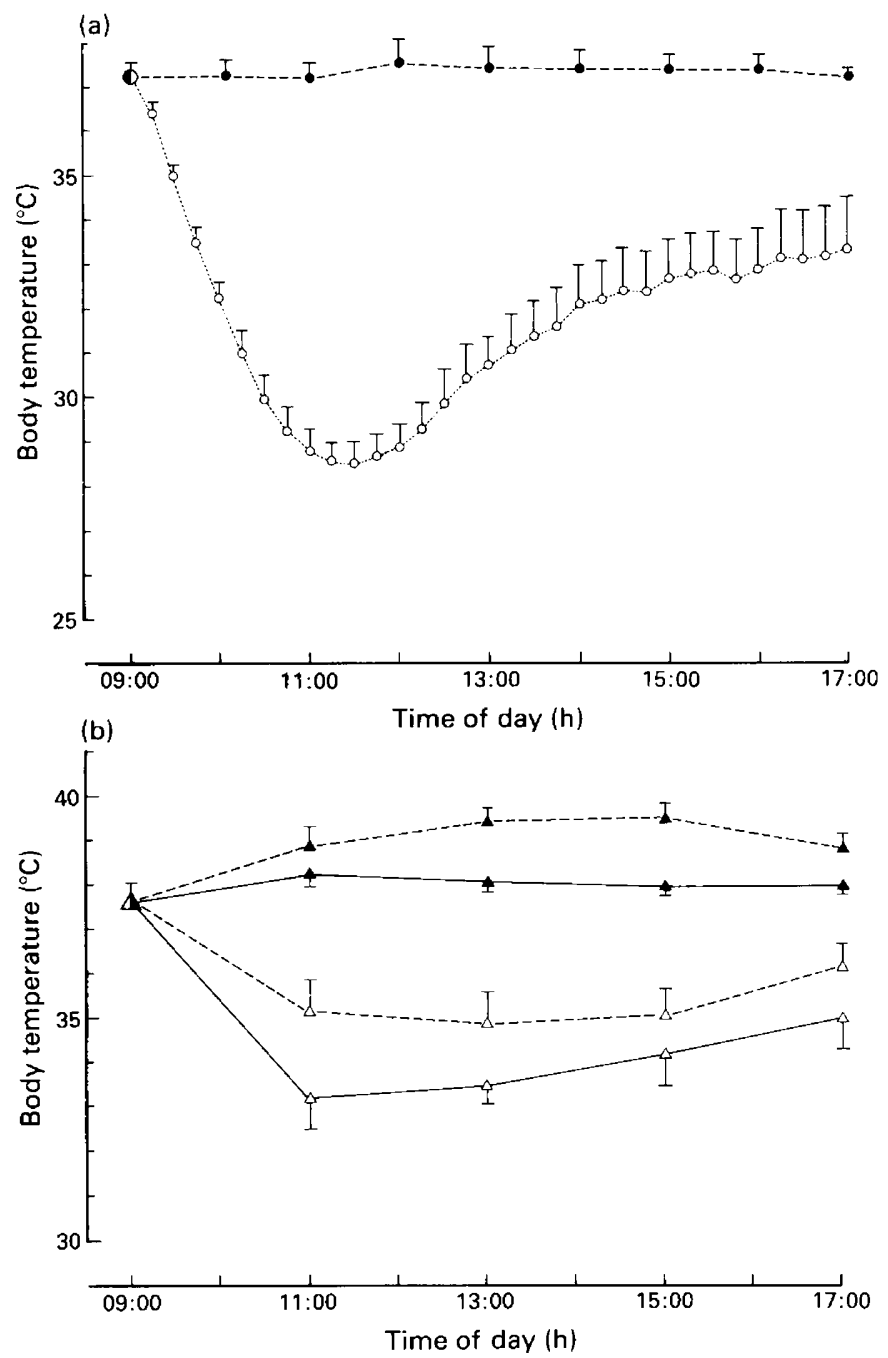

Fig. 1. Effect of Nembutal given at $09: 00 \mathrm{~h}$ in pro-oestrus on body temperature. (a) (O) controls; (O) Nembutal-treated rats kept at a room temperature of $21 \pm 1{ }^{\circ} \mathrm{C}$. Both groups contained nine rats. (b) Effect of increased ambient temperature on body temperature changes after injection of Nembutal. After injection of Nembutal the rats were kept at an ambient temperature of $\left(\mathbf{\Delta - - - \Delta )} 34 \cdot 5,\left(\mathbf{\Delta - \Delta )} 33,(\triangle---\triangle) 32\right.\right.$ and $(\triangle-\triangle) 31^{\circ} \mathrm{C}$; six rats were tested at each temperature. Data are means and SEM.

\section{Experiment 2}

On the day of pro-oestrus, $1000 \mathrm{ng}$ of $\mathrm{GnRH}$ at 10:00 h caused a transient rise in plasma $\mathrm{LH}$ and did not interfere with the LH surge beginning at about 12:00 h (Fig. 2). Nembutal given $1 \mathrm{~h}$ after GnRH prevented the surge of LH. Nembutal delayed the meiotic process by about $2 \mathrm{~h}$, and delayed ovulation (Table 2).

\section{Experiment 3}

Injection of $100 \mathrm{ng}$ of Ovalyse at 10:00 h during pro-oestrus caused a significantly greater rise in LH concentration (Fig. 3) than did $1000 \mathrm{ng}$ of $\mathrm{GnRH}(P<0.001)$. Administration of Nembutal 


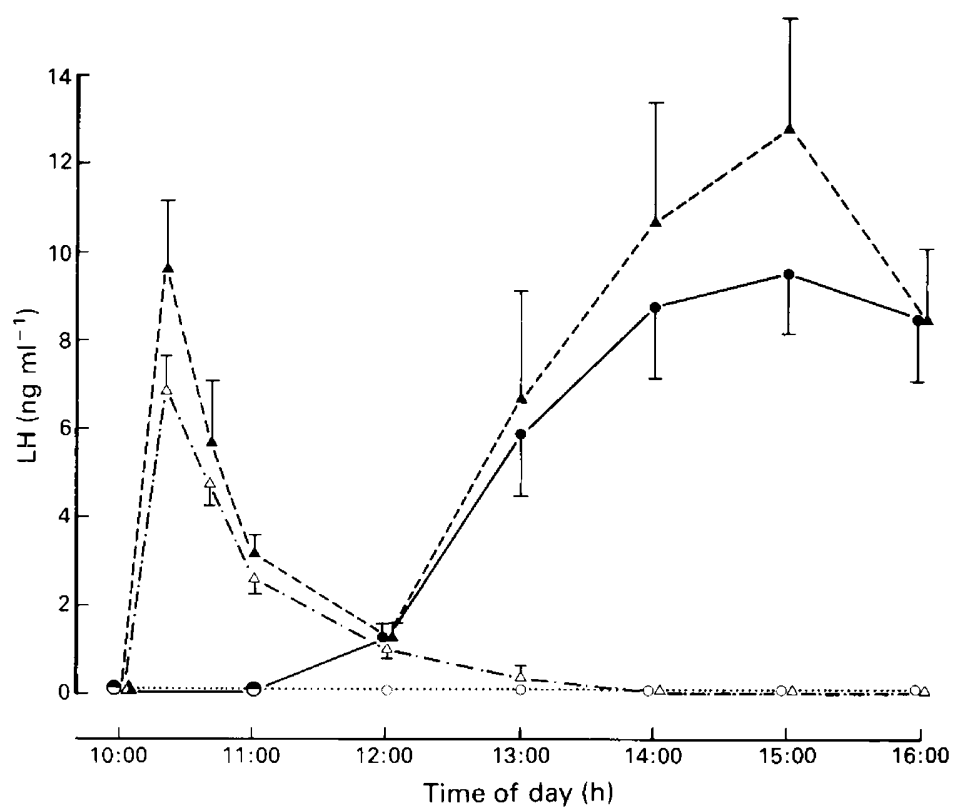

Fig. 2. Plasma profiles of luteinizing hormone $(\mathrm{LH})$ during pro-oestrus. ( $)$ the LH surge $(n=$ 9); (O) the suppressive effect of Nembutal given at 11:00 h on this surge $(n=9) ;(\boldsymbol{\Delta})$ the effect of $1000 \mathrm{ng}$ gonadotrophin-releasing hormone $(\mathrm{GnRH})$ given at 10:00 h in pro-oestrus on release of LH $(n=7)$ and $(\triangle)$ summarizes the effect of $\mathrm{GnRH}$ at 10:00 h followed by Nembutal at 11:00 $\mathrm{h}$ on release of LH $(n=7)$. Data are means and SEM.

Table 2. Effect of Nembutal on meiosis and ovulation, induced by $1000 \mathrm{ng}$ gonadotrophin-releasing hormone $(\mathrm{GnRH})$. GnRH was given at 10:00 h during pro-oestrus and followed by saline or Nembutal at $11.00 \mathrm{~h}$

\begin{tabular}{|c|c|c|c|c|c|c|}
\hline \multirow{3}{*}{$\begin{array}{l}\text { Interval between } \\
\text { GnRH and section } \\
\text { Number of rats }\end{array}$} & \multicolumn{3}{|c|}{ Saline } & \multicolumn{3}{|c|}{ Nembutal } \\
\hline & $10 \mathrm{~h}$ & $12 \mathrm{~h}$ & $14 \mathrm{~h}$ & $10 \mathrm{~h}$ & $12 \mathrm{~h}$ & $14 \mathrm{~h}$ \\
\hline & 5 & 5 & 5 & 6 & 6 & 6 \\
\hline \multicolumn{7}{|l|}{ Follicle stages: } \\
\hline MAT & 0 & 0 & 0 & $7 \cdot 9 \pm 2 \cdot 2^{*}$ & $2 \cdot 5 \pm 1 \cdot 6$ & 0 \\
\hline Metaphase II plus PB & $11 \cdot 2 \pm 0 \cdot 6$ & $1.6 \pm 0.7$ & $0.2 \pm 0.2$ & $5 \cdot 2 \pm 2 \cdot 4$ & $8 \cdot 0 \pm 1 \cdot 8^{*}$ & $0 \cdot 2 \pm 0 \cdot 2$ \\
\hline Metaphase II, no PB & $2 \cdot 0 \pm 0.5$ & $8.8 \pm 1.6$ & $2 \cdot 4 \pm 0.5$ & $0^{*}$ & $2 \cdot 8 \pm 0 \cdot 9^{*}$ & $11.8 \pm 0.5^{*}$ \\
\hline Ruptured follicles & 0 & $1.8 \pm 0.7$ & $11.6 \pm 0.7$ & 0 & $0^{*}$ & $1 \cdot 0 \pm 0 \cdot 4^{*}$ \\
\hline
\end{tabular}

MAT comprises metaphase I, anaphase and telophase. PB: polar body; *significant effect compared to the same follicular stage of corresponding control group. Values given are mean \pm SEM.

did not interfere with the ongoing Ovalyse-induced release of LH (Fig. 3). In the samples taken at 13:00-14:00 h in Ovalyse-Nembutal rats, LH concentration was lower than in the corresponding samples of the Ovalyse-saline group $(P<0.01)$, indicating that Nembutal suppressed the spontaneous LH surge. Ovulation rates after injection of Ovalyse on day 3 of dioestrus at 16:00 h and on pro-oestrus at 09:00 h were similar (Table 3). Nembutal had an ovulation-delaying effect of about $2 \mathrm{~h}$ at $21^{\circ} \mathrm{C}$, but not when body temperature of the rats was kept at $37^{\circ} \mathrm{C}$.

\section{Experiment 4}

During pro-oestrus $1000 \mathrm{ng}$ of $\mathrm{LH}$ given at $00: 00 \mathrm{~h}$ triggered meiotic resumption in $60-80 \%$ of the large follicles. At $10 \mathrm{~h}$ after $\mathrm{LH}$, these oocytes had all reached metaphase II. Nembutal given 


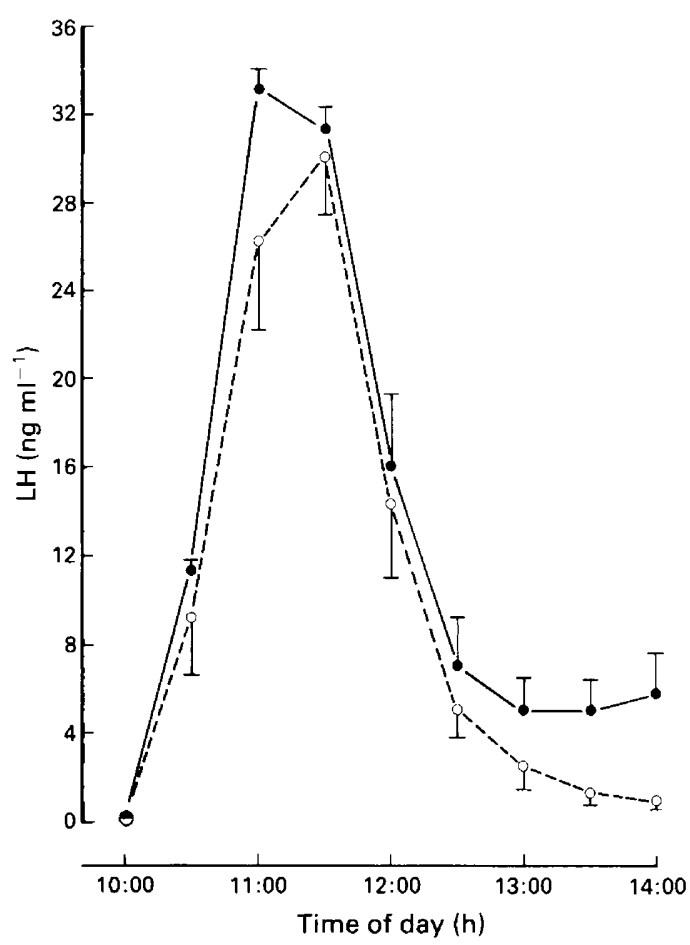

Fig. 3. Plasma profiles of luteinizing hormone $(\mathrm{LH})(\mathbf{)})$ after injection of $100 \mathrm{ng}$ Ovalyse at 10:00 h in pro-oestrus; $(O)$ the effect of $100 \mathrm{ng}$ Ovalyse at 10:00 h, followed by Nembutal at 11:00 h pro-oestrus. Both groups contained nine rats. Data are means and SEM.

Table 3. Ovulation rate expressed as ruptured follicles, induced by $100 \mathrm{ng}$ of Ovalyse

\begin{tabular}{lcccc}
\hline $\begin{array}{l}\text { Interval between } \\
\text { Ovalyse and section }\end{array}$ & \multicolumn{2}{c}{ Saline } & \multicolumn{2}{c}{ Nembutal } \\
\hline & A & B & $\mathrm{C}$ & $\mathrm{D}$ \\
$12 \mathrm{~h}$ & $2 \cdot 5 \pm 0 \cdot 6$ & $2 \cdot 3 \pm 0 \cdot 6$ & 0 & 0 \\
$14 \mathrm{~h}$ & $8 \cdot 7 \pm 1 \cdot 8$ & $9 \cdot 2 \pm 1 \cdot 4$ & $0 \cdot 8 \pm 0 \cdot 5^{*}$ & $10 \cdot 0 \pm 0 \cdot 4$ \\
$16 \mathrm{~h}$ & $12 \cdot 6 \pm 0 \cdot 8$ & $12 \cdot 8 \pm 0 \cdot 9$ & $9 \cdot 3 \pm 1 \cdot 1$ & $13 \cdot 2 \pm 0 \cdot 6$ \\
$18 \mathrm{~h}$ & $\mathrm{ND}$ & $\mathrm{ND}$ & $11 \cdot 0 \pm 0 \cdot 7$ & $\mathrm{ND}$ \\
\hline
\end{tabular}

Ovalyse given at (A) $16: 00 \mathrm{~h}$ on day 3 of dioestrus followed by saline at $17.00 \mathrm{~h}$; (B) 10:00 $\mathrm{h}$ pro-oestrus, followed by saline at $11 \cdot 00 \mathrm{~h}$; (C, D) 10:00 h during prooestrus followed by Nembutal at 11:00 h. (D) experiment was performed at $33^{\circ} \mathrm{C}$ ambient temperature. Groups of four rats were killed at 12, 14, 16 and $18 \mathrm{~h}$, respectively, after injection of Ovalyse. Values given are mean \pm SEM. ND: not determined. *Significant effect compared with value at $14 \mathrm{~h}$ of groups $\mathrm{B}$ and $D$.

10 min after $\mathrm{LH}$ retarded meiotic progress significantly at an ambient temperature of $21^{\circ} \mathrm{C}$, but not at an ambient temperature of $33^{\circ} \mathrm{C}$.

\section{Discussion}

These results corroborate the suggestion that Nembutal inhibits secretion of $\mathrm{GnRH}$, but has no direct effect on release of LH (Blake \& Sawyer, 1972; Fink et al., 1976). Nembutal also retarded 
meiotic progress. Vermeiden \& Zeilmaker (1974) found that metaphase II was reached sooner after injection of pituitary extract in hypophysectomized rats than after injection of hCG in Nembutaltreated rats; this was attributed to different properties of the injected materials. An effect of Nembutal on the rate of meiosis may have been unnoticed, because in their study the interval between hCG and Nembutal varied.

We found that in unanaesthetized rats, most Graafian follicles had ovulated 14-16 h after administration of the stimulating factor; ovulation was retarded when Nembutal was given subsequent to the stimulation. Sridaran et al. (1979) did not report a delaying effect of phenobarbital on ovulation. However, their trials were at a room temperature $4 \mathrm{C}$ higher, whereas the interval between $\mathrm{LH}$ and phenobarbital was at least $3 \mathrm{~h}$. It is also conceivable that phenobarbital has less effect on body temperature than Nembutal.

Holsinger \& Everett (1972) found that ovulation occurred in a restricted period of the night, regardless of the time of stimulation by gonadotrophin. This observation was not confirmed by Sridaran et al. (1979). In this study, ovulation was complete 14-16 h after injection of Ovalyse, regardless of whether ovulation was induced at 16:00 h on day 3 of dioestrus or at 10:00 h in prooestrus. Also oocyte maturation occurred at a similar rate, regardless of whether it was induced at $00: 00$ or 10:00 $\mathrm{h}$ in pro-oestrus; this confirms an observation by Vermeiden \& Zeilmaker (1974).

Nembutal is known for its hypothermic effect. The Nembutal dose that is generally used to block GnRH release and that consequently prevents spontaneous ovulation causes a profound reduction of body temperature (Ishikawa \& Suzuki, 1986; Simpkins \& Katovich, 1987; Wixson et al., 1987). Simpkins \& Katovich (1987) kept their rats at an ambient temperature of $26^{\circ} \mathrm{C}$ after injection of Nembutal and found a decrease in body temperature to $30-32^{\circ} \mathrm{C}$. We measured a drop to below $30^{\circ} \mathrm{C}$, when the temperature of the room was $21^{\circ} \mathrm{C}$; and the fall of body temperature could be prevented at increased ambient temperature. The data indicate that Nembutal impairs temperature regulation rather than changing the hypothalamic set-point temperature.

Nembutal has an activity like GABA ( $\gamma$-amino-butyric acid) (Roberts, 1987). GnRH neuronal activity is inhibited by GABA (Weiner et al., 1988). The anaesthetizing and temperature-lowering effects of Nembutal are assumed also to be caused by GABA-like effects on the central nervous system (Chwey et al., 1987). Sites binding GABA are also found in granulosa cells (Schaeffer \& Hsueh, 1982; Hsueh et al., 1984). Local administration of GABA has been reported to affect ovarian blood flow (Erdö et al., 1985). It is unlikely that the delaying effect of Nembutal on meiosis and ovulation are caused by GABA-like effects of the drug in the ovary, because this retardation was not observed when a decrease in body temperature was prevented. $A$ decrease in body temperature may slow down biochemical reactions including processes involved in meiosis and ovulation. Since a delay of these processes was prevented by raising ambient temperature, we conclude that these delaying effects of Nembutal were mediated entirely by an effect of Nembutal on body temperature.

We thank NIDDK (Betheseda, MD, USA) for providing LH-RIA materials and the National Hormone and Pituitary Program (University of Maryland School of Medicine) for providing rat LH for injection. We are grateful to Upjohn Company, Ede, The Netherlands, for providing Ovalyse. Leen Blok, Gerry Wagenaar and Inca Kusters gave excellent technical assistance. J. C. Rigg (Pudoc, Wageningen) advised on the formulation of the text. K. Boekhorst made the drawings. The research was carried out within the framework of the Agricultural University's working party on early pregnancy.

\section{References}

Blake, C.A. \& Sawyer, C.H. (1972) Ovulation blocking actions of urethane in the rat. Endocrinology 91, 87-94.
Chwey, A.J., Swinyard, E.A. \& Wolf, H.H. (1987) Hypnotic action of pentobarbital in mice: a possible mechanism. Experimental Neurology 97, 70-76. 
Daane, T.A.P. \& Parlow, F. (1971) Peri-ovulatory patterns of rat serum FSH during the normal oestrous cycle: effects of pentobarbital. Endocrinology 88, 653-663.

Erdö, S.L., Varga, B. \& Horveth, E. (1985) Effect of local GABA administration on rat ovarian blood flow, and on progesterone and estradiol secretion. European Journal of Pharmacology 111, 397-400.

Everett, J.W. \& Sawyer, C.H. (1950) A 24-hour periodicity in the 'LH-release apparatus' of female rats, disclosed by barbiturate sedation. Endocrinology 47, 198-218.

Everett, J.W., Sawyer, C.H. \& Markee, J.E. (1949) A neurogenic timing factor in control of the ovulatory discharge of luteinizing hormone in the cyclic rat. Endocrinology 44, 234250.

Fink, G., Chiappa, S.A. \& Aiyer, M.S. (1976) Priming effect of luteinizing hormone releasing factor elicited by preoptic stimulation and by intravenous infusion and multiple injections of the synthetic decapeptide. Journal of Endocrinology 69, 359-372.

Gill, J.L. \& Hafs, D. (1971) Analyses of repeated measurements of animals. Journal of Animal Science 33, 331-336.

Holsinger, J.W. \& Everett, J.W. (1972) Prolonged interval to ovulation in rats after preoptic stimulation on the morning of proestrus. Endocrinology 90, 289-290.

Hsueh, A.J.W., Adashi, E.Y., Jones, P.B.C. \& Welsh, T.H. (1984) Hormonal regulation of the differentiation of cultured ovarian granulosa cells. Endocrinology Reviews 5, 76-127.

Ishikawa, K. \& Suzuki, M. (1986) Antagonism by TRH of pentobarbital-induced hypothermia in rats with brain lesions. Experientia 42, 1027-1031.

Janocko, L. \& Mycek, M.J. (1986) Prolonged hypothermia after phenobarbital-induced anesthesia in adrenalectomized rats. Pharmacology Biochemistry and Behaviour 24, 1651-1658.

Mattheij, J.A.M. \& Van Pijkeren, T.A. (1977) Plasma prolactin in undisturbed cannulated male rats: effects of perphenazine, frequent blood sampling, stress and castration plus oestrone treatment. Acta Endocrinologica 84, 51-61.
Mattheij, J.A.M., De Boer, P., Dekker, B., Rijnders, E. \& Swarts, J.J.M. (1986) Administration of human chorionic gonadotropin but not of luteinizing hormonereleasing hormone at pro-oestrus or late di-oestrus has a deleterious effect on pregnancy in the rat. Gynecologic and Obstetric Investigation 22, 84-90.

Roberts, E. (1987) GABA. In Encyclopedia of Neuroscience, Vol. I, pp. 441-444. Ed. G. Adelman. Birkhäuser, Boston.

Schaeffer, J.M. \& Hsueh, A.J.W. (1982) Identification of gamma-aminobutyric acid and its binding sites in the ovary. Life Science 30, 1599-1604.

Simpkins, J.W. \& Katovich, M.J. (1987) Role of hypothermia in the pentobarbital-induced blockade of LH secretion in female rats. Neuroendocrinology 46, 217-221

Snedecor, G.W. \& Cochran, W.G. (1989) Statistical Methods (8th edn). Iowa University Press, Ames.

Sridaran, R., Rodriguez-Sierra, J.F. \& Blake C.A. (1979) Ovarian involvement in the timing mechanism that controls ovulation in rats. Biology of Reproduction 21, 505-509.

Tsafriri, A.P.\& Kraicer, P.F. (1972) The time sequence of ovum maturation in the rat. Journal of Reproduction and Fertility 29, 387-393.

Van Der Schoot, P. (1980) Delay of ovulation in rats with sodium pentobarbitone: apparent differences between rats with 4-day or 5-day reproductive cycles. Journal of Endocrinology 86, 451-457.

Vermeiden, J.P.W. \& Zeilmaker, G.H. (1974) Relationship between maturation division, ovulation and luteinization in the female rat. Endocrinology 95, $341-351$.

Weiner, R.I., Findell, P.R. \& Kordon, C.L. (1988) Role of classic and peptide neuromediators in the neuroendocrine regulation of $\mathrm{LH}$ and prolactin. In The Physiology of Reproduction, pp. 1235-1281. Eds E. Knobil \& J. D. Neill. Raven Press, New York.

Wixson, S.K., White, W.J., Hughes, H.C., Lang, H.C. \& Marshall, W.K. (1987) The effect of pentobarbital fentanyldoperidol, ketamine-xylazine and ketaminediazepam on core and surface body temperature regulation in the adult male rat. Laboratory Animal Science 37, 743-749.

Received 13 June 1991 